\title{
Anthropometric profile of elite Azerbaijani senior greco-roman wrestlers
}

\author{
Rahmani F. ${ }^{1 \mathrm{ABCDE}}$, Mirzaei B. ${ }^{1 \mathrm{ABCDE}}$, Faradjzadeh Mevaloo S. ${ }^{2 \mathrm{ABCDE}}$ \\ ${ }^{1}$ Faculty of Physical Education and Sport Sciences, University of Guilan, Iran \\ ${ }^{2}$ Center for Strategic Research and Studies, I.R.I. Ministry of Sport and Youth, Tehran, Iran
}

Authors' Contribution: A - Study design; B - Data collection; C - Statistical analysis; D - Manuscript Preparation; E - Funds Collection.

\begin{tabular}{|c|c|}
\hline \multicolumn{2}{|l|}{ Abstract } \\
\hline Purpose: & $\begin{array}{l}\text { The aim of this study was to describe the anthropometric profile of elite Azerbaijani senior Greco-Roman } \\
\text { wrestlers. }\end{array}$ \\
\hline Material: & $\begin{array}{l}\text { Twenty three elite level wrestlers in the preparation camp of national team of Azerbaijan (age } 27.21 \\
\pm 2.71 \text { years, weight } 81.36 \pm 19.30 \mathrm{~kg} \text { and training experience } 8.5 \pm 3 \text { years) participated in this study } \\
\text { as subjects. Body composition features including body mass, body mass index (BMI), lean body mass } \\
\text { (LBM) and body fat and anthropometric indices: girth, breadth, SUM of skinfolds in } 8 \text { points based on the } \\
\text { international society for the advancement of kinanthropometry (ISAK) protocol, basic variables including } \\
\text { stretch stature and somatotype have been measured. }\end{array}$ \\
\hline Results: & $\begin{array}{l}\text { The mean and standard deviations of the measurements of elite Azerbaijani senior Greco-Roman } \\
\text { wrestlers were: stretch stature }(172.85 \pm 8.37 \mathrm{~cm}) \text {, body mass index }(26.76 \pm 3.79 \text { lean body mass }(73.66 \pm \\
14.41) \text {, body fat }(8.69 \pm 4.46) \text {, waist girth }(81.76 \pm 8.85) \text {, gluteal girth }(98.2 \pm 8.39) \text {, arm girth relaxed }(34.19 \\
\pm 3.82) \text {, arm girth flexed and tensed }(36.39 \pm 3.66) \text {, calf girth }(38.64 \pm 4.13) \text {, humerus breadth }(7.24 \pm \\
0.61) \text {, femur breadth }(10.09 \pm 0.75) \text {, SUM of skinfold at } 8 \text { points }(58.19 \pm 32.44) \text {, somatotype: endomorphy } \\
(2.01 \pm 1.05) \text {, mesomorphy }(6.94 \pm 1 / 23) \text {, ectomorphy }(1 / 19 \pm 0 / 66) \text {. }\end{array}$ \\
\hline Conclusions: & $\begin{array}{l}\text { Access to the anthropometric profile of elite wrestlers helps coaches to identify talented athletes and } \\
\text { then assist them to lead their wrestlers to achieve superiority and elation by principled and scientific } \\
\text { planning. }\end{array}$ \\
\hline & \\
\hline
\end{tabular}

\section{Introduction}

Greco-Roman wrestling is a weight-categorized sport, thus, the body composition of athletes determines the weight category in which the athlete competes [1]. Body composition is related to controlling the weight of wrestlers and it is a relevant factor which affects the athlete's performance [2]. Today, sports scientists and coaches benefit from various anthropometric techniques in important areas such as sports talent identification, assessing body composition, measuring exercise outcomes and physical abilities [3-5]. A wrestling coach can prevent the loss of essential body fat and, consequently, prevent the occurrence of athletic performance disorders using simple anthropometric equations. Paying attention to these concepts is one of the necessities of coaching science for any wrestling coach [3]. According to sport sciences, selecting appropriate human resources is the most important factor to improve the sportive skills qualitatively and quantitatively. Therefore, it seems that this is necessary to get better and more precise knowledge of talents in order to promote the quality levels of different sports and athletes [6]. Anthropometric profiling of the elite wrestlers, while describing the existing conditions, would be a criterion for other wrestlers to be assessed and this information can be used for talent identification [7].

Considering the importance of the issue, a significant part of the studies on the physical fitness of wrestlers has been done on the physiological and anthropometric

(c) Rahmani F., Mirzaei B. , Farajdzadeh Mevaloo S., 2019

doi:10.15561/18189172.2019.0406 profiles of a wrestling team [8-10] and in some cases only one wrestler $[11,12]$.

Casals et al [1] in a study compared the anthropometric profile of 32 elite Serbian Greco-Roman wrestlers by their body mass in three categories of light weight, middle weight, and heavy weight. Their somatotypes were also determined by the Heath-Carter method. The statistical results showed $(\mathrm{r}=-0.70, \mathrm{p}<0.001)$ for endomorphy, $(\mathrm{r}=-0.68, \mathrm{p}<0.001)$ for mesomorphy, and $(\mathrm{r}=0.79$, $\mathrm{p}<0.001)$ for ectomorphy. The calculated body fat percentage in 6 skinfolds including triceps, subscapular, supraspinal, abdomen, thigh, and medial calf skinfolds; showing similar percentages in light and middle-weight categories, while heavier athletes presented higher body fat percentages. In a study, Zaccagni [13] studied anthropometric characteristics and the body composition of Italian national wrestlers. The study was carried out on a sample of 23 wrestlers ( 9 females and 14 males) aged 18-33 years. Various anthropometric measurements were performed (weight, height, sitting height, some girths and skinfold thicknesses) and anthropometric indices calculated (body mass index, cormic index, upper arm muscle area, upper arm fat area, and arm fat index). Body composition was assessed and minimum wrestling weight was determined based on a minimum body fat percentage of $5 \%$ for males and $12 \%$ for females.

Vardar et al [14] investigated the relationship between body composition and anaerobic performance in young elite wrestlers in a study. Eight female (age 16.2 \pm 1.1 
years) and eight male (age 17.3 \pm 0.9 years) wrestlers from the Turkish junior national team participated in this study. Fat free mass (FFM) and percent fat mass (\%FM) were carried out through electric bioimpedance. Anaerobic performance was assessed by the Wingate test

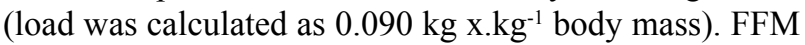
was greater in male wrestlers $(65.4 \pm 12.3 \mathrm{~kg})$ than female wrestlers $(45.1 \pm 4.6 \mathrm{~kg}, \mathrm{p}<0.01) . \% \mathrm{FM}$ was lower in male wrestlers $(9.7 \pm 6.3)$ than female wrestlers $(18.5 \pm 2.8 ; \mathrm{p}<$ $0.01)$. Mean power was significantly correlated with FFM in both genders. No relationship was obtained between anaerobic parameters and \%FM.

A full scale of the anthropometric profile of the Azerbaijani national team is not provided, yet. Therefore, this study has been carried out by anthropometric measurements and profile of the wrestlers of national team in order to provide a framework for assessing wrestlers and talent identification in Azerbaijan.

\section{Materials and Methods}

\section{Participants}

Twenty three elite wrestlers (age $27.21 \pm 2.71$ years, weight $81.36 \pm 19.30 \mathrm{~kg}$ and training experience $8.5 \pm 3$ years) of the senior national wrestling team of Azerbaijan participated in the study.

\section{Research Design}

A descriptive research study was conducted with elite senior Greco-Roman wrestlers. Body composition features including body mass, body mass index (BMI), lean body mass (LBM) and body fat and anthropometric indices: girth (waist, hip, arm and leg), breadth (elbow and knee), SUM of skinfolds in 8 points based on the international society for the advancement of kinanthropometry (ISAK) protocol [15], basic variables including stretch stature and somatotype (endomorphy, mesomorphy and ectomorphy) have been measured. All wrestlers were assessed during the general preparation phase of the season.

\section{Statistical Analysis}

Before analysis, normality of the distribution was analyzed using Shapiro-Wilk test. Descriptive statistics were used to calculate the mean and standard deviations of collected data. The level of significance for all statistics was set at $p<0.05$. SPSS 25 , software was used to calculate the data.

\section{Results}

Tables 1 to 5 show individual characteristics, body composition, girth, breadth and somatotype of elite Azerbaijani senior Greco-Roman wrestlers.

Table 1. Mean and standard deviation of individual characteristics of the elite Azerbaijani senior Greco-Roman wrestlers

\begin{tabular}{llll}
\hline Weight Class & Age (years) & Body Mass $(\mathbf{k g})$ & Stretch stature $(\mathbf{c m})$ \\
\hline $55 \mathrm{~kg}(\mathrm{n}=2)$ & $25.5 \pm 2.12$ & $60 \pm 2.12$ & $162.5 \pm 3.35$ \\
$60 \mathrm{~kg}(\mathrm{n}=2)$ & $24.5 \pm 2.12$ & $62.55 \pm 0.07$ & $162.75 \pm 2.47$ \\
$63 \mathrm{~kg}(\mathrm{n}=2)$ & $27 \pm 4.24$ & $65 / 75 \pm 0.35$ & $166.1 \pm 4.38$ \\
$67 \mathrm{~kg}(\mathrm{n}=3)$ & $29 \pm 0.0$ & $71.16 \pm 3.21$ & $168.83 \pm 1.04$ \\
$72 \mathrm{~kg}(\mathrm{n}=2)$ & $29 \pm 1.41$ & $73.75 \pm 1.06$ & $170 \pm 1.41$ \\
$77 \mathrm{~kg}(\mathrm{n}=3)$ & $28 \pm 4.35$ & $79.66 \pm 2.25$ & $175 \pm 1.73$ \\
$82 \mathrm{~kg}(\mathrm{n}=3)$ & $28.33 \pm 2.30$ & $82.66 \pm 2.75$ & $177.66 \pm 3.51$ \\
$87 \mathrm{~kg}(\mathrm{n}=2)$ & $25.5 \pm 3.53$ & $88.75 \pm 5.30$ & $173.5 \pm 6.36$ \\
$97 \mathrm{~kg}(\mathrm{n}=1)$ & $24 \pm 0.0$ & $106 \pm 0.0$ & $175 \pm 0.0$ \\
$130 \mathrm{~kg}(\mathrm{n}=3)$ & $27.66 \pm 2.51$ & $121.06 \pm 7.75$ & $183.83 \pm 1.04$ \\
Total $(n=23)$ & $27.21 \pm 2.71$ & $81.36 \pm 19.30$ & $172.85 \pm 8.37$ \\
\hline
\end{tabular}

Table 2. Mean and standard deviation of the body composition of the elite Azerbaijani senior Greco-Roman wrestlers

\begin{tabular}{llll}
\hline Weight Class & BMI $\left(\mathbf{k g} / \mathbf{m}^{2}\right)$ & LBM $(\mathbf{k g})$ & Body fat $(\%)$ \\
\hline $55 \mathrm{~kg}(\mathrm{n}=2)$ & $22.75 \pm 1.76$ & $57.05 \pm 1.34$ & $4.8 \pm 1.13$ \\
$60 \mathrm{~kg}(\mathrm{n}=2)$ & $23.65 \pm 0.77$ & $58.95 \pm 0.35$ & $5.8 \pm 0.42$ \\
$63 \mathrm{~kg}(\mathrm{n}=2)$ & $23.85 \pm 1.34$ & $61.7 \pm 0.28$ & $6.15 \pm 0.91$ \\
$67 \mathrm{~kg}(\mathrm{n}=3)$ & $24.96 \pm 1.37$ & $65.83 \pm 4.31$ & $7.56 \pm 2.01$ \\
$72 \mathrm{~kg}(\mathrm{n}=2)$ & $25.55 \pm 0.07$ & $68.6 \pm 0.56$ & $7 \pm 2.12$ \\
$77 \mathrm{~kg}(\mathrm{n}=3)$ & $26.03 \pm 0.89$ & $74.13 \pm 2.34$ & $6.96 \pm 0.81$ \\
$82 \mathrm{~kg}(\mathrm{n}=3)$ & $26.2 \pm 1.49$ & $75.06 \pm 1.44$ & $9.16 \pm 1.27$ \\
$87 \mathrm{~kg}(\mathrm{n}=2)$ & $29.5 \pm 0.42$ & $80.5 \pm 9.05$ & $9.45 \pm 4.73$ \\
$97 \mathrm{~kg}(\mathrm{n}=1)$ & $34.6 \pm 0.0$ & $87 \pm 0.0$ & $18 \pm 0.0$ \\
\hline
\end{tabular}


Continuation Table 2.

\begin{tabular}{llll}
\hline Weight Class & BMI $\left(\mathbf{k g} / \mathbf{m}^{2}\right)$ & LBM $(\mathbf{k g})$ & Body fat (\%) \\
\hline $130 \mathrm{~kg}(\mathrm{n}=3)$ & $32.9 \pm 3.75$ & $102.86 \pm 6.71$ & $14.8 \pm 7.66$ \\
Total $(\mathrm{n}=23)$ & $26.76 \pm 3.79$ & $73.66 \pm 14.41$ & $8.69 \pm 4.46$
\end{tabular}

Note: $\mathrm{BMI}=$ Body Mass Index, LBM = Lean Body Mass

Table 3. Mean and standard deviation of girth of the elite Azerbaijani senior Greco-Roman wrestlers

\begin{tabular}{llllll}
\hline Weight Class & $\begin{array}{l}\text { Arm girth } \\
\text { relaxed }(\mathbf{c m})\end{array}$ & $\begin{array}{l}\text { Arm girth } \\
\text { flexed and } \\
\text { tensed }(\mathbf{c m})\end{array}$ & $\begin{array}{l}\text { Waist girth } \\
(\mathbf{c m})\end{array}$ & $\begin{array}{l}\text { Gluteal girth } \\
(\mathbf{c m})\end{array}$ & Calf girth $(\mathbf{c m})$ \\
\hline $55 \mathrm{~kg}(\mathrm{n}=2)$ & $30 \pm 0.0$ & $33.15 \pm 0.49$ & $72.75 \pm 3.18$ & $88 \pm 2.82$ & $33.25 \pm 1.06$ \\
$60 \mathrm{~kg}(\mathrm{n}=2)$ & $30.09 \pm 0.14$ & $32.09 \pm 0.84$ & $76.4 \pm 0.84$ & $93 \pm 2.82$ & $36.4 \pm 1.97$ \\
$63 \mathrm{~kg}(\mathrm{n}=2)$ & $30.4 \pm 0.14$ & $33.1 \pm 0.14$ & $72.55 \pm 0.77$ & $89 \pm 2.82$ & $35.7 \pm 0.42$ \\
$67 \mathrm{~kg}(\mathrm{n}=3)$ & $33.16 \pm 1.25$ & $35.16 \pm 1.65$ & $78.2 \pm 1.96$ & $94.6 \pm 3.31$ & $37.36 \pm 1.25$ \\
$72 \mathrm{~kg}(\mathrm{n}=2)$ & $33.4 \pm 1.97$ & $35 \pm 2.54$ & $79.85 \pm 1.90$ & $92.6 \pm 2.26$ & $36.75 \pm 1.06$ \\
$77 \mathrm{~kg}(\mathrm{n}=3)$ & $33.8 \pm 1.70$ & $35.86 \pm 1.28$ & $77.6 \pm 1.22$ & $98.06 \pm 3.0$ & $37.96 \pm 1.26$ \\
$82 \mathrm{~kg}(\mathrm{n}=3)$ & $33 \pm 0.86$ & $35.33 \pm 0.28$ & $83.8 \pm 3.01$ & $99.2 \pm 2.30$ & $37.93 \pm 1.51$ \\
$87 \mathrm{~kg}(\mathrm{n}=2)$ & $37.3 \pm 0.42$ & $39.25 \pm 1.06$ & $83.1 \pm 4.38$ & $102.3 \pm 2.40$ & $40.1 \pm 1.27$ \\
$97 \mathrm{~kg}(\mathrm{n}=1)$ & $40.6 \pm 0.0$ & $42.5 \pm 0.0$ & $97.3 \pm 0.0$ & $110 \pm 0.0$ & $43.3 \pm 0.0$ \\
$130 \mathrm{~kg}(\mathrm{n}=3)$ & $40.63 \pm 3.67$ & $42.9 \pm 2.97$ & $98.36 \pm 6.78$ & $113.03 \pm 6.95$ & $47.13 \pm 2.64$ \\
Total $(\mathrm{n}=23)$ & $34.19 \pm 3.82$ & $36.39 \pm 3.66$ & $81.76 \pm 8.85$ & $98.02 \pm 8.39$ & $38.64 \pm 4.13$ \\
\hline
\end{tabular}

Table 4. Mean and standard deviation of breadth of the elite Azerbaijani senior Greco-Roman wrestlers

\begin{tabular}{lll}
\hline Weight Class & Humerus breadth $(\mathbf{c m})$ & Femur breadth $(\mathbf{c m})$ \\
\hline $55 \mathrm{~kg}(\mathrm{n}=2)$ & $6.8 \pm 0.56$ & $9.25 \pm 0.07$ \\
$60 \mathrm{~kg}(\mathrm{n}=2)$ & $6.7 \pm 0.14$ & $9.45 \pm 0.07$ \\
$63 \mathrm{~kg}(\mathrm{n}=2)$ & $6.75 \pm 0.49$ & $9.35 \pm 0.21$ \\
$67 \mathrm{~kg}(\mathrm{n}=3)$ & $7.13 \pm 0.11$ & $9.8 \pm 0.17$ \\
$72 \mathrm{~kg}(\mathrm{n}=2)$ & $7.05 \pm 0.21$ & $9.65 \pm 0.07$ \\
$77 \mathrm{~kg}(\mathrm{n}=3)$ & $7.02 \pm 0.20$ & $10.1 \pm 0.36$ \\
$82 \mathrm{~kg}(\mathrm{n}=3)$ & $7.03 \pm 0.05$ & $10.3 \pm 0.36$ \\
$87 \mathrm{~kg}(\mathrm{n}=2)$ & $7.35 \pm 0.49$ & $10.75 \pm 0.63$ \\
$97 \mathrm{~kg}(\mathrm{n}=1)$ & $7.8 \pm 0.0$ & $10.4 \pm 0.0$ \\
$130 \mathrm{~kg}(\mathrm{n}=3)$ & $8.46 \pm 0.64$ & $11.43 \pm 0.66$ \\
Total $(n=23)$ & $7.24 \pm 0.61$ & $10.09 \pm 0.75$
\end{tabular}

Table 5. Mean and standard deviation of somatotype of the elite Azerbaijani senior Greco-Roman wrestlers

\begin{tabular}{llll}
\hline Weight Class & Endomorphy & Mesomorphy & Ectomorphy \\
\hline $55 \mathrm{~kg}(\mathrm{n}=2)$ & $1.1 \pm 0.42$ & $6.05 \pm 0.07$ & $1.9 \pm 0.98$ \\
$60 \mathrm{~kg}(\mathrm{n}=2)$ & $1.4 \pm 0.0$ & $6.5 \pm 0.70$ & $1.5 \pm 0.42$ \\
$63 \mathrm{~kg}(\mathrm{n}=2)$ & $1.45 \pm 0.21$ & $5.95 \pm 0.07$ & $1.65 \pm 0.77$ \\
$67 \mathrm{~kg}(\mathrm{n}=3)$ & $1.5 \pm 0.40$ & $6.9 \pm 0.55$ & $1.36 \pm 0.55$ \\
$72 \mathrm{~kg}(\mathrm{n}=2)$ & $1.75 \pm 0.77$ & $6.4 \pm 0.70$ & $1.15 \pm 0.07$ \\
$77 \mathrm{~kg}(\mathrm{n}=3)$ & $1.76 \pm 0.30$ & $6.53 \pm 0.64$ & $1.3 \pm 0.36$ \\
$82 \mathrm{~kg}(\mathrm{n}=3)$ & $2.16 \pm 0.49$ & $5.96 \pm 0.83$ & $1.43 \pm 0.55$ \\
$87 \mathrm{~kg}(\mathrm{n}=2)$ & $2.5 \pm 1.55$ & $8.15 \pm 0.49$ & $0.4 \pm 0.28$ \\
\hline
\end{tabular}


Cont. Table 5.

\begin{tabular}{llll}
\hline Weight Class & Endomorphy & Mesomorphy & Ectomorphy \\
\hline $97 \mathrm{~kg}(\mathrm{n}=1)$ & $4.3 \pm 0.0$ & $9.2 \pm 0.0$ & $0.1 \pm 0.0$ \\
$130 \mathrm{~kg}(\mathrm{n}=3)$ & $3.13 \pm 1.79$ & $8.76 \pm 1.30$ & $0.6 \pm 0.70$ \\
Total $(n=23)$ & $2.01 \pm 1.05$ & $6.94 \pm 1.23$ & $1.19 \pm 0.66$ \\
\hline
\end{tabular}

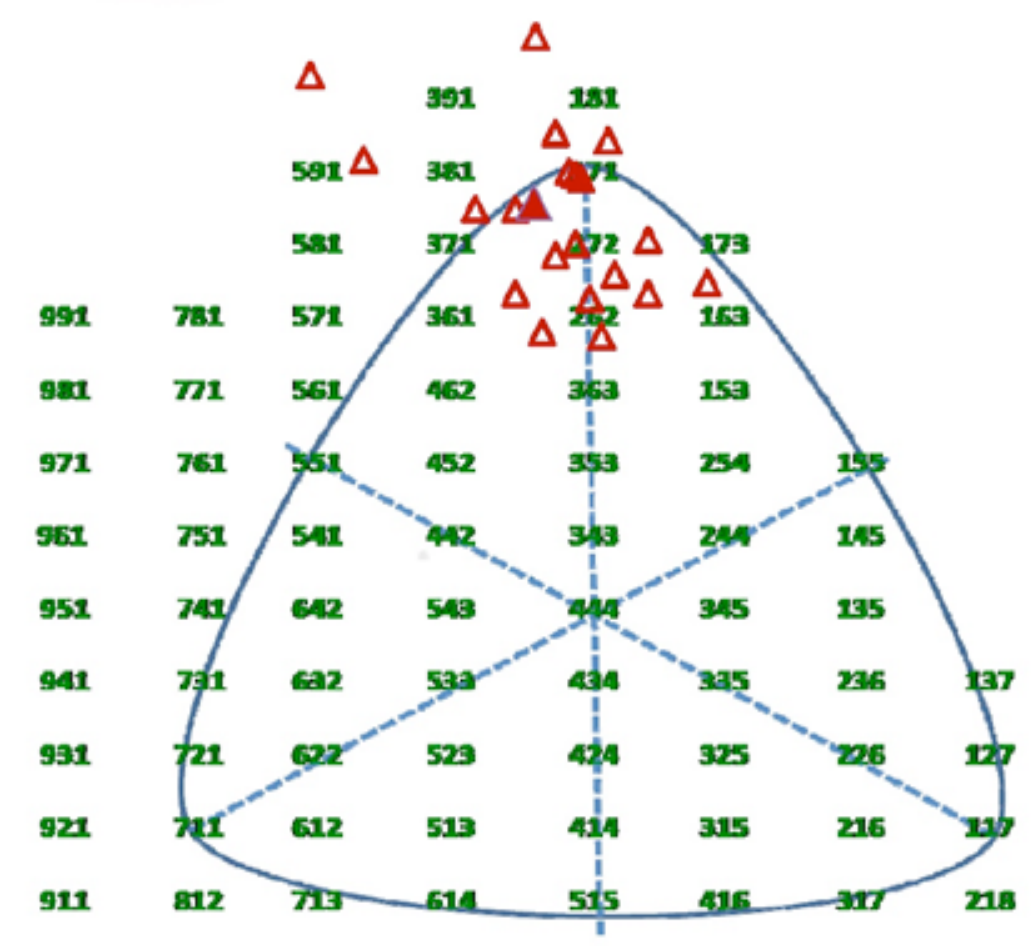

Figure 1. Somatotype features of elite Azerbaijani senior Greco-Roman wrestlers. $\Delta=$ somatotype mean (1.19 - 6.94 $-2.01)$

\section{Discussion}

Assessing of anthropometric profile of elite wrestlers helps coaches to identify talented athletes and then assists them to lead their wrestlers to achieve superiority and elation by principled and scientific planning. The lack of anthropometric profiles of the elite wrestlers of Azerbaijan on the one hand and the lack of unanimity of the implemented protocols by other studies in other countries have made it impossible to compare the results of this study with other countries. However, the findings of this study were compared with other findings that examine the anthropometric characteristics of elite wrestlers.

The results of Table 1 show that the mean stretch stature and weight of wrestlers in this study were similar to those findings of Mirzaei et al [16], whose stretch stature was $172.9 \mathrm{~cm}$ and weight, $81.5 \mathrm{~kg}$.

The results of Table 2 indicate that the wrestlers of Azerbaijani senior national team have a high fat percentage in the weight of 97 and $130 \mathrm{~kg}$ category, and their lean body mass is very different from the weight they should compete ( $10 \mathrm{~kg}$ for the wrestlers of $97 \mathrm{~kg}$ and about $20 \mathrm{~kg}$ for the wrestlers of $130 \mathrm{~kg}$ ), this situation affects the performance of these wrestlers.

Wrestlers with higher body fat are faced with an overweight due to excess body fat during aerobic activities that weakens their performance. Unnecessary fat creates more resistance to exercise, thereby forces the wrestler to increase the specific muscle strength of the contraction to a given task. Excess body fat can limit endurance, balance, coordination, and motor capacity. The motion range of the joint can be negatively affected by weight and excess fat, and the weight can be a physical barrier against joint movement in a full range of motion [17].

In addition, the results of Table 2 show that the mean body mass index was similar to Mirzaei et al [16], which reported 26.9. However, it was more than the findings of the Zaccagni's study [13], which reported 24.29 and Vardar's [14] of 24.1.

Body mass index is one of the indicators for determining appropriate weight or overweight. Because of higher muscle tissue, the BMI of wrestlers is more than normal and in a range of 26 to 32 [18].

The average lean body mass of the Azerbaijani wrestlers was higher than the findings of the study by Ratamess et al [19], which reported $67.1 \mathrm{~kg}$. In addition, it was similar to the findings of the study by Mirzaei et al [16] that reported the number of $71.8 \mathrm{~kg}$.

The mean fat percentage was similar to the findings of Arabac1 et al [20], which reported a fat percentage of 5.8, and also with Yoon's [21], which reported an appropriate 
fat percentage of 7-10 percent for wrestlers. However, the findings of the study were less than those by Ratmess et al [19] and Mirzaei et al [16], who reported $11.3 \%$ and Zaccagni [13], who reported $10.4 \%$.

In many sports fields, especially wrestling that are weight classified, the athlete's ability to perform properly depends to some extent on the correct control of his body fat.

The results of Table 3 show that the mean of the girth of the Azerbaijani wrestlers was similar to the results of Rahmati et al [22], who reported arm girth relaxed as 34.5 $\mathrm{cm}$, the arm girth flexed and tensed as $37.77 \mathrm{~cm}$, the waist girth as $83.88 \mathrm{~cm}$ and the calf girth as $54 / 38 \mathrm{~cm}$. However, it was higher in the hip girth, which was $36 / 90 \mathrm{~cm}$.

The results of Table 4 show that the wrestlers' breadth corresponded to the findings of the study by Rahmati et al [22], which reported the breadth of elbow 74.7 and the breadth of knee to be $85 / 10$.

Anthropometric experts use elbow and knee bone breadth to assess athletes' capacity to gain more muscle tissues. Farajdzadeh et al [3] showed that the breadth between the two ankles of the wrestlers' right foot is a good indicator of predicting these athletes' capacity of lean tissue. It means that, the more this breadth is, the higher capacity to gain muscle tissue a wrestler would have.

The results of Table 5 show that the elite Azerbaijani senior Greco-Roman wrestlers have a mesomorphic endomorphic body type.

The determination of somatotype is used to describe and compare the body structure of athletes at all competitive levels. It can also be used to control changes in body structure during growth stages, sport exercises and in association with physical performance $[18,23]$.

\section{Conclusion}

In general, it is recommended that coaches evaluate the anthropometric status of wrestlers regularly in order to improve the performance of the training programs and compare the results with other elite wrestlers. In addition, the results of these measurements can be used as a basis for early talent identification.

\section{Acknowledgements}

The authors would like to thank the study participants for their dedication and effort throughout the study.

\section{Conflicts of interest}

The authors declare no conflict of interest.

\section{References}

1. Casals C, López-Gullón JM, Trivic T, Drid P. Somatotypes and anthropometric profile of elite Serbian Greco-Roman wrestlers. International Scientific and Professional Conference on Wrestling "Applicable Research in Wrestling". 2017; P.128.

2. Buford TW, Smith DB, O'Brien MS, Warren AJ, Rossi SJ. Seasonalchangesofbodymass, bodycomposition, andmuscular performance in collegiate wrestlers. International journal of sports physiology and performance. 2008;3(2):176- 84 . https://doi.org/10.1123/ijspp.3.2.176

3. Faradjzadeh Sh. Kinanthopometry (Coaches Guide). First ed. Tehran: N.O.C.I.R. Iran; 2006.

4. Jagiello W, Jagiello M, Kalina RM, Barczynski BJ, Litwiniuk A, Klimczak J. Properties of body composition of female representatives of the Polish national fencing team - the sabre event. Biology of Sport. 2017;34(4):401-406. https:// doi.org/10.5114/biolsport.2017.70526

5. Volodchenko OA, Podrigalo LV, Iermakov SS, Zychowska MT, Jagiello W. The Usefulness of Performing Biochemical Tests in the Saliva of Kickboxing Athletes in the Dynamic of Training. Biomed Research International. 2019;2019:7. https://doi.org/10.1155/2019/2014347

6. Hadavi F, Zarifi A. Talent identification and development model in Iranian athletics. World J Sport Sci. 2009;2(4):24853.

7. Mirzaei B, Mansour Sadeghi M. The profile of physical fitness of the adult wrestlers taking part in national team of freestyle wrestling preparation expeditions. The Journal of Olympics, 2006;15(38):81-89.

8. Kraemer WJ, Fry AC, Rubin MR, Triplett-McBride T, Gordon SE, Koziris LP, Lynch JM, Volek JS, Meuffels DE, Newton RU, Fleck SJ. Physiological and performance responses to tournament wrestling. Medicine and science in sports and exercise. 20011;33(8):1367-78. https://doi.org/10.1097/00005768-200108000-00019

9. Kraemer WJ, Vescovi JD, Dixon P. The physiological basis of wrestling: Implications for conditioning programs. Strength \& Conditioning Journal. 2004;26(2):10-15. https://doi.org/10.1519/00126548-200404000-00001

10. Yamashita D, Arakawa H, Arimitsu T, Wada T, Yumoto K, Fujiyama K, Nagami T, Shimizu S. Physiological Profiles of International-and Collegiate-Level Japanese Male Freestyle Wrestlers in the Lightweight Classes. International Journal of Wrestling Science. 2017;7(1-2):21-25. https://doi.org/10.1080/21615667.2017.1341572

11. Mirzaei B, Curby DG, Barbas I, Lotfi N. Anthropometric and physical fitness traits of four-time World Greco- Roman wrestling champion in relation to national norms: A case study. Journal of Human Sport and Exercise. 2011;6(2):406- 413. https://doi.org/10.4100/jhse.2011.62.21

12.Utter AC, O'bryant HS, Haff GG, Trone GA. Physiological profile of an elite freestyle wrestler preparing for competition: a case study. Journal of strength and conditioning research. 2002;16(2):308-315. https://doi.org/10.1519/00124278-200205000-00022

13.Zaccagni L. Anthropometric characteristics and body composition of Italian national wrestlers. European Journal of Sport Science. 2012;12(2):145- 51. https://doi.org/10.1080/17461391.2010.545838

14.Vardar SA, Tezel S, Öztürk L, Kaya O. The relationship between body composition and anaerobic performance of elite young wrestlers. Journal of sports science \& medicine. 2007;6(CSSI-2):34.

15.International Standards for Anthropometric Assessment. First ed. The International Society for the Advancement of Kinanthropometry; 2001. P. 53-112.

16.Mirzaei B, Ghafouri A. Physiological profile of the wrestlers of the senior national team. The Journal of Sports Physiology Research, 2007;3(5):57-66 
17.Miller T. NSCA's guide to tests and assessments. First ed. Colorado: Human Kinetics. United States; 2012.

18.Sedaghati, P. Applied kinanthropometry. First ed. Tehran: Boshra. Iran; 2017.

19.Ratamess NA, Hoffman JR, Kraemer WJ, Ross RE, Tranchina CP, Rashti SL, Kelly NA, Vingren JL, Kang J, Faigenbaum AD. Effects of a competitive wrestling season on body composition, endocrine markers, and anaerobic exercise performance in NCAA collegiate wrestlers. European Journal of Applied Physiology. 2013;113(5):1157- 68. https://doi.org/10.1007/s00421-012-2520-8

20.Arabacı R, Topçu H, Vardar T. The relationship between some physical fitness characteristics and body composition of elite wrestlers. International Journal of Physical Education, Fitness and Sports. 2019;8(1):25- 32. https://doi.org/10.26524/ijpefs 1913
21.Yoon J. Physiological profiles of elite senior wrestlers. Sports Medicine. 2002;32(4):225-33.

22.Rahmati M, Sadeghi H, Farjad pezeshk A. Anthropometric, physiological and biomechanical profiles of senior GrecoRoman Iranian wrestlers. Paper presented at first national conference on physical education and sport sciences, Najafabad, Islamic Azad University, Najafabad Branch; 2012. P. 2-3.

23.Cherkashin IA, Krivoruchenko EV, Jagiello W, Iermakov SS, Podrigalo LV. Optimization of physical training of the qualified muay thai athletes of light weight categories. Archives of Budo Science of Martial Arts and Extreme Sports. 2018;14:31-43.

\section{Information about the authors:}

Rahmani F.; (Corresponding author); http://orcid.org/0000-0001-7570-0026; m.foadrahmani@yahoo.com; Faculty of Physical Education and Sport Sciences, University of Guilan ; P.O Box: 1438, Rasht, Iran.

Mirzaei B.; http://orcid.org/0000-0003-3723-7434; bmirzaei2000@yahoo.com; Faculty of Physical Education and Sport Sciences, University of Guilan ; P.O Box: 1438, Rasht, Iran.

Faradjzadeh Mevaloo S.; http://orcid.org/0000-0002-6706-889X; sfaradjzadeh@yahoo.com; Center for Strategic Research and Studies, I.R.I. Ministry of Sport and Youth; Vanak square, Jahan-e-koudak highway, Sanei street, Amir Parviz tower, first floor unit 13, Postal Code 1969955111, Tehran, Iran.

Cite this article as:

Rahmani F, Mirzaei B, Farajdzadeh Mevaloo S. Anthropometric profile of elite Azerbaijani senior greco-roman wrestlers. Pedagogics, psychology, medical-biological problems of physical training and sports, 2019;23(4):196-201. https://doi.org/10.15561/18189172.2019.0406

This is an Open Access article distributed under the terms of the Creative Commons Attribution License, which permits unrestricted use, distribution, and reproduction in any medium, provided the original work is properly cited (http://creativecommons.org/licenses/by/4.0/deed.en).

Received: 30.05 .2019

Accepted: 30.06.2019; Published: 29.08.2019 